\title{
Asymmetric Total Synthesis of Pyranicin
}

\author{
Michael T. Crimmins ${ }^{*}$ and Danielle L. Jacobs \\ Kenan \& Caudill Laboratories of Chemistry, University of North Carolina at Chapel Hill, Chapel Hill, \\ North Carolina, 27599
}

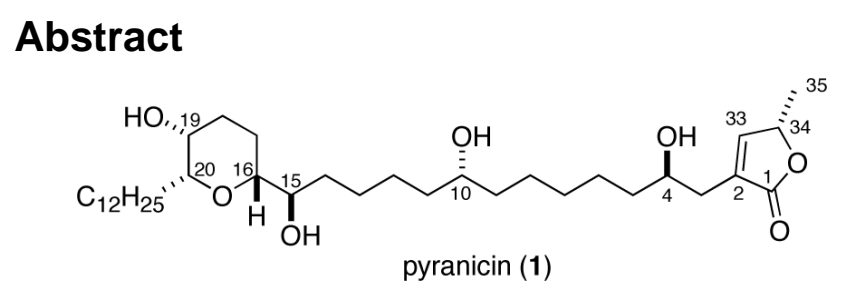

The asymmetric total synthesis of pyranicin (1) is reported. The butenolide ring was constructed via an asymmetric alkylation/ring-closing metathesis strategy. The three stereocenters in the left-hand tetrahydropyran ring were installed by sequential chiral auxiliary-mediated aldol reactions. Closure of the tetrahydropyran and fusion of the alkyl backbone were affected via a sequential ring-closing metathesis cross-metathesis strategy.

\begin{abstract}
Pyranicin (1), a novel member of the annonaceous acetogenin family of natural products, was isolated in 1997 by McLaughlin and coworkers from the stem bark of the Goniothalamus giganteus tree native to Thailand.1 Since 1982, over 400 molecules in the annonaceous acetogenin family have been identified, but pyranicin is one of only two known acetogenins to bear a tetrahydropyran (THP) ring. ${ }^{2}$ These 35 - or 37 -carbon polyether natural products typically possess a terminal $\gamma$-methylbutenolide, and are capped with a long hydrophobic alkyl chain. Annonaceous acetogenins are the most powerful inhibitors of mitochondrial Complex I (NADH-ubiquinone oxidoreductase) in both mammalian and insect electron transport systems. It is believed that their ability to interrupt the final electron transfer from NADH to ubiquinone decreases cellular ATP production, leading to cell death by apoptosis. This unique mode of biological activity has characterized the acetogenins as promising anti-feedant and pesticide treatments, as well as anti-malarial, anti-parasitic, and anti-tumor drugs, and they have recently exhibited promising results against Parkinsonism.3 Pyranicin, in particular, demonstrates selective in vitro cytotoxicity $\left(\mathrm{ED}_{50} 10^{-2} \mu \mathrm{g} / \mathrm{mL}\right)$ against human pancreatic adenocarcinomal cell lines (PACA-2). ${ }^{1}$ Recent studies have further revealed in vivo cytotoxicity ( ID $_{50} 9.4 \mu \mathrm{M}$ ) of pyrancin against the growth of promyelocytic leukemia cells (HL-60), alternatively attributed to its ability to inhibit DNA polymerase in the cancerous cells. ${ }^{4}$ The interesting structures and and potent bilogical activity have made the annonaceous acetogenins the subject of a significant amount of synthetic work.5 The first total synthesis of pyranicin was accomplished by Nakata and Takahashi6 with subsequent reports by Rein, 7 Makabe $^{8}$ and Phillips. ${ }^{9}$
\end{abstract}

Herein we describe an enantioselective total synthesis of pyranicin, taking advantage of chlorotitanium enolates of $\mathrm{N}$-glycolyloxazolidinones to establish the syn 1,2-oxygen relationship at $\mathrm{C} 15-\mathrm{C} 16$ and $\mathrm{C} 19-\mathrm{C} 20 .{ }^{10}$ The pyranicin carbon backbone was envisioned to

crimmins@email.unc.edu.

Supporting Information Available Experimental procedures and copies of ${ }^{1} \mathrm{H}$ and ${ }^{13} \mathrm{C}$ NMR spectra. This material is available via the Internet at http://pubs.acs.org. 
arise from a tandem ring-closing metathesis (RCM) - cross metathesis (CM) reaction that would close the tetrahydropyran ring from triene $\mathbf{2}$ while concurrently joining the tetrahydropyran unit and butenolide fragment 3 (Figure 1). Dihydropyran precursor $\mathbf{2}$ would be accessed via an asymmetric glycolate aldol addition of glycolyloxazolidinone $\mathbf{4}$ and aldehyde $\mathbf{5}$. The butenolide ring would be constructed via esterification of acrylic acid 7 with (S)-3-buten-2-ol (6), followed by RCM.

Aldehyde 5 was prepared from $(S)$-benzylglycidyl ether as illustrated in Scheme 1. Lewis acid promoted addition ${ }^{11}$ of lithiated homopropargyl alcohol $\mathbf{8}$ to $(S)$-benzyl glycidyl ether provided alkyne 9. The alkyne was reduced and removal of the benzyl group was accomplished employing Raney nickel to deliver diol 10. Selective sulfonylation of the primary alcohol was best affected employing 2,4,6-triisopropylsulfonylchloride (TrisCl) under standard conditions whereupon treatment with base afforded epoxide 11. Subsequently, the $(S)$-epoxide underwent copper (I) promoted reaction with butenylmagnesium bromide to provide alcohol 12. Ensuing alcohol protection, selective removal of the PMB ether, ${ }^{12}$ and Swern oxidation ${ }^{13}$ of the primary alcohol provided the target aldehyde $\mathbf{5}$ in good yield over three steps.

Preparation of triene $\mathbf{2}$ began with a glycolate aldol reaction between benzylglycolyloxazolidinone $\mathbf{1 3}$ and tridecanal, providing aldol adduct $\mathbf{1 4}$ in good yield and excellent diastereoselectivity (Scheme 1). ${ }^{10}$ This reaction established the stereocenters at C19 and C20 at an early stage. The secondary alcohol was then protected as its triethylsilyl (TES) ether, and the chiral auxiliary was reductively removed with lithium borohydride.

Oxidation ${ }^{13}$ of primary alcohol $\mathbf{1 5}$ followed by Wittig methylenation provided the protected diol, which was selectively deprotected under fluoride conditions to give secondary alcohol 16. Subsequent alkylation of the free alcohol with bromoacetic acid gave the glycolic acid, and further transformation into glycolylimide $\mathbf{4}$ was accomplished via nucleophilic addition of lithiated oxazolidinone $\mathbf{1 7}$ to the intermediate mixed pivaloyl anhydride. ${ }^{14}$

A second titanium-mediated glycolate aldol reaction ${ }^{10}$ with aldehyde 5 established the stereocenters at $\mathrm{C} 15$ and $\mathrm{C} 16$ providing the aldol adduct $\mathbf{1 8}$ in $74 \%$ yield ( $>95: 5 \mathrm{dr}$ ). The RCM precursor $\mathbf{2}$ was prepared from aldol adduct $\mathbf{1 8}$ by a four step sequence. Protection of the C15 hydroxyl as its TES ether followed by reductive removal of the auxiliary gave the primary alcohol 19. Dess-Martin oxidation ${ }^{15}$ of the alcohol to the aldehyde and final methylenation completed the synthesis of triene $\mathbf{2}$.

Our efforts were directed next towards the preparation of $\gamma$-methylbutenolide 3 . The C34 stereocenter was to be installed via esterifcation using (S)-3-buten-2-ol (6). Although the enantiomer of the alcohol had previously been prepared in our total synthesis of giganticin, 16 the volatility of the alcohol $\left(\mathrm{bp}=92^{\circ} \mathrm{C}\right.$ ) created difficulty with its successful isolation. In an attempt to ease the problems with isolation of alcohol $\mathbf{6}$, while still maintaining the necessary terminal olefin functionality for the ensuing RCM reaction, we investigated the use of alcohol 22 in an alternative relay ring-closing metathesis (RRCM) strategy, recently demonstrated by Hoye $^{17}$ (Scheme 2). We anticipated that while the increased molecular weight of the ether fragment of alcohol 22 would effectively improve the isolation of the chiral alcohol, the additional atoms would be removed as dihydrofuran during the ensuing relay metathesis, providing butenolide $\mathbf{3}$. The synthesis of bis-allylic ether $\mathbf{2 2}$ was thus pursued. L-Ethyl lactate was protected as its $t$-butyldiphenylsilyl (TBDPS) ether 20, which was subsequently reduced to the corresponding aldehyde (Scheme 2). Olefination of the intermediate aldehyde employing carboethoxymethylene triphenylphsophorane yielded $\alpha, \beta$-unsaturated ester 21, which was then reduced to the allylic alcohol. Alkylation of the alcohol with allyl bromide gave the allyl ether, which was exposed to $n$ - $\mathrm{Bu}_{4} \mathrm{NF}$ to provide the desired alcohol 22 in $80 \%$ over two steps. 
The synthesis of acrylate 7 began with installation of the $\mathrm{C} 4$ stereocenter via asymmetric alkylation ${ }^{18}$ of $p$-methoxybenzylglycolyloxazolidinone $\mathbf{2 3}$ with allylic iodide $\mathbf{2 4},{ }^{19}$ giving protected allyl alcohol 25 with high (>95:5) diastereoselectivity (Scheme 2). Reductive removal of the chiral auxiliary unmasked a primary alcohol 26, which allowed for conversion to the terminal alkene via Swern ${ }^{13}$ oxidation and subsequent olefination with methylenetriphenylphsophorane. Removal of the primary TBS ether followed by a two-stage oxidation yielded the corresponding acrylic acid 7. Esterification of acid $\mathbf{7}$ with alcohol 22 was best affected via the intermediate mixed pivaloyl anhydride. Initial attempts at closure of the butenolide under standard RRCM conditions only gave the corresponding ring-opened diene 29, presumably formed after the initial expulsion of dihydrofuran, followed by intermolecular carbene transfer. However, by sparging the reaction with argon, we were able to increase the yield of butenolide 3 from $23 \%$ to $70 \%$, without any trace of straight-chain byproduct $29 .{ }^{20}$

The completion of the synthesis required the closure of the tetrahydropyran ring via a ringclosing metathesis and assembly of the THP and butenolide fragments through a crossmetathesis reaction (Scheme 3). Given the expected rapid closure of the tetrahydropyran and the difference in reactivity between the $\mathrm{C} 5$ alkene of the butenolide and the $\mathrm{C} 6$ alkene of the tetrahydropyran unit, it was hoped that the two processes could be accomplished concurrently in a single exposure to a ruthenium carbene. ${ }^{21}$

Despite the differences in the reactivities of the two coupling fragments, however, the ensuing tandem $\mathrm{RCM} / \mathrm{CM}$ reaction proved to be quite difficult to control and suitable conditions for the tandem sequence could not be identified. The best results were found when the cross metathesis was performed between the ring-closed monomer $\mathbf{3 0}$ and butenolide $\mathbf{3}$. Therefore, it was necessary to isolate the ring-closed monomer before subjecting to cross metathesis with butenolide $\mathbf{3}$. In the event, triene $\mathbf{2}$ was exposed to the Grubbs second generation catalyst ${ }^{22}$ to close the tetrahydropyran ring. After the ring-closing metathesis product $\mathbf{3 0}$ was isolated in quantitative yield, the cross metathesis between alkene $\mathbf{3 0}$ and butenolide $\mathbf{3}$ was achieved with the Hoveyda-Grubbs catalyst ${ }^{23}$ in $58 \%$ yield based on recovered starting material.

Finally, exposure of triene $\mathbf{3 1}$ to excess tosylhydrazine and sodium acetate in aqueous dimethoxyethane at reflux, ${ }^{24}$ resulted in selective hydrogenation of the C17-C18 and C5-C6 alkenes and removal of the triethylsilyl protecting group, while leaving the butenolide olefin in tact. Subjection of the resultant butenolide to $\mathrm{BF}_{3}-\mathrm{OEt}_{2}$ - in dimethyl sulfide provided pyranicin $(\mathbf{1})$ in $68 \%$ yield. The synthetic sample was identical in all aspects $\left({ }^{1} \mathrm{H},{ }^{13} \mathrm{C},[\mathrm{a}]{ }^{\mathrm{D}}\right)$ to the natural product. ${ }^{1}$

In summary, a highly convergent total synthesis of pyranicin (1) has been completed. The key fragments were constructed employing asymmetric glycolate aldol and alkylation reactions followed by ring-closing metatheses; a cross metathesis was utilized to convergently construct the backbone of the natural product.

\section{Supplementary Material}

Refer to Web version on PubMed Central for supplementary material.

\section{Acknowledgments}

Financial support from the National Institute of General Medical Sciences (GM60567)) is gratefully acknowledged. We gratefully acknowledge a generous gift of $(S)$-benzylglycidyl ether from Daiso, Inc.

\section{References}

(1). Alali FQ, Rogers L, Zhang Y, McLaughlin JL. Tetrahedron 1998;54:5833-5844. 
(2). Bermejo A, Figadére B, Zafra-Polo M-C, Barrachina I, Estornell E, Cortes D. Nat. Prod. Rep 2005;22:269-303. [PubMed: 15806200]

(3). For a recent review see McLaughlin JL. J. Nat. Prod 2008;71:1311-1321. [PubMed: 18598079] .

(4). (a) Takahashi S, Yonezawa Y, Kubota A, Ogawa N, Maeda K, Koshino H, Nakata T, Yoshida H, Mizushina Y. Inter. J. Onc 2008;32:451-458. (b) Ishimaru C, Takeuchi T, Yonezawa Y, Kuriyama I, Takemura M, Kato I, Sugawara F, Yoshida H, Mizushina Y. Lett. Drug Design Disc 2007;4:239_ 245.

(5). For a recent review see Li N, Shi ZH, Tang Y, Chen J, Li X. Beilstein J. Org. Chem 2008;4(48) doi. 10.3762/bjoc.4.48. .

(6). Takahashi S, Kubota A, Nakata T. Org. Lett 2003;5:1353-1356. [PubMed: 12688757]

(7). Strand D, Rein T. Org. Lett 2005;7:199-202. [PubMed: 15646957] Strand D, Norrby PO, Rein T. J. Org. Chem 2006;71:1879-1891. [PubMed: 16496972]

(8). (a) Hattori Y, Furuhata S, Okajima M, Konno H, Abe M, Miyoshi H, Goto T, Makabe H. Org. Lett 2008;10:717-720. [PubMed: 18251547] (b) Furuhata S, Hattori Y, Okajima M, Konno H, Abe M, Miyoshi H, Goto T, Makabe H. Tetrahedron 2008;64:7695-7703.

(9). Griggs ND, Phillips AJ. Org. Lett 2008;10:4955-4957. [PubMed: 18844364]

(10). Crimmins MT, She J. Synlett 2004:1371-1374.

(11). Yamaguchi M, Hirao I. Tetrahedron Lett 1983;24:391-394.

(12). Horita K, Yoshioka T, Tanaka T, Oikawa Y, Yonemitsu O. Tetrahedron 1986;42:3021-3028.

(13). Mancuso AJ, Huang S-L, Swern D. J. Org. Chem 1978;43:2480-2482.

(14). Gage JR, Evans DA. Org. Synth 1990;68:77-82.

(15). Dess DB, Martin JC. J. Org. Chem 1983;48:4155-4156.Ireland RE, Liu L. J. Org. Chem 1993;58:2899.Dess DM, Martin JC. J. Am. Chem. Soc 1991;113:7277-7287.

(16). Crimmins MT, She J. J. Am. Chem. Soc 2004;126:12790-12791. [PubMed: 15469270]

(17). Hoye TR, Jeffrey CS, Tennakoon MA, Wang JZ, Zhao HY. J. Am. Chem. Soc 2004;126:1021010211. [PubMed: 15315410]

(18). Crimmins MT, Emmitte KA, Katz JD. Org. Lett 2000;2:2165-2167. [PubMed: 10891257]

(19). a) Villieras J, Rambaud M. Synthesis 1982:924-926. b) Villieras J, Rambaud M. Org. Synth 1988;66:220-224.

(20). Nosse B, Schall A, Jeong WB, Reiser O. Adv. Synth. Catal 2005;347:1869-1874.

(21). Scholl M, Ding S, Lee CW, Grubbs RH. Org. Lett 1999;1:953-956. [PubMed: 10823227]

(22). Chatterjee AK, Choi TL, Sanders DP, Grubbs RH. J. Am. Chem. Soc 2003;125:11360-11370. [PubMed: 16220959]

(23). Garber SB, Kingsbury JS, Gray BL, Hoveyda AH. J. Am. Chem. Soc 2000;122:8168-8179.

(24). For examples see a) Marshall JA, Chen M. J. Org. Chem 1997;62:5996-6000.. b) Crimmins MT, Zhang Y, Diaz FA. Org. Lett 2006;8:2369-2372. [PubMed: 16706528] . c) ref 8. 


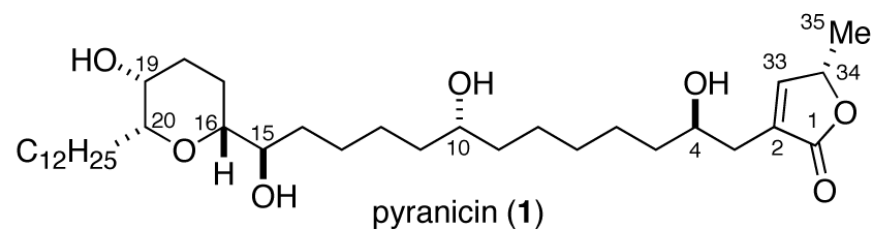<smiles>C=C[C@H](CC1=C[C@@H](C)OC1=O)O[C@H](C=C)CC1=C[C@@H](C)OC1=O</smiles>

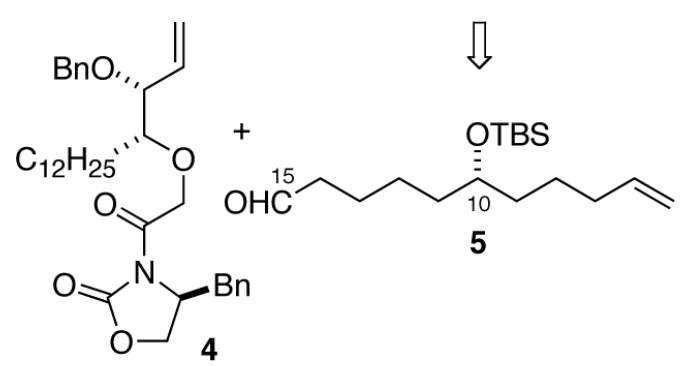

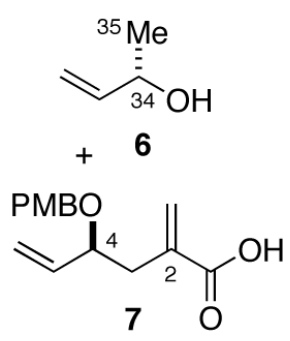

Figure 1.

Original retrosynthesis of pyranicin 


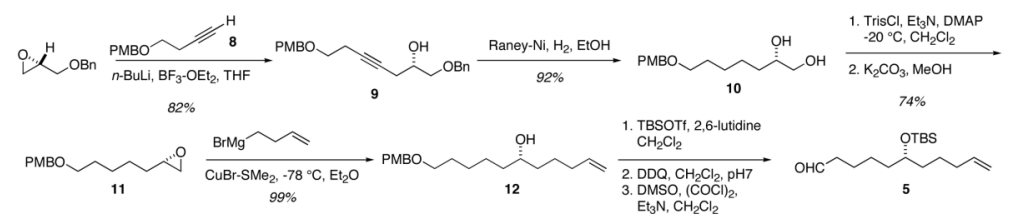

$80 \%$
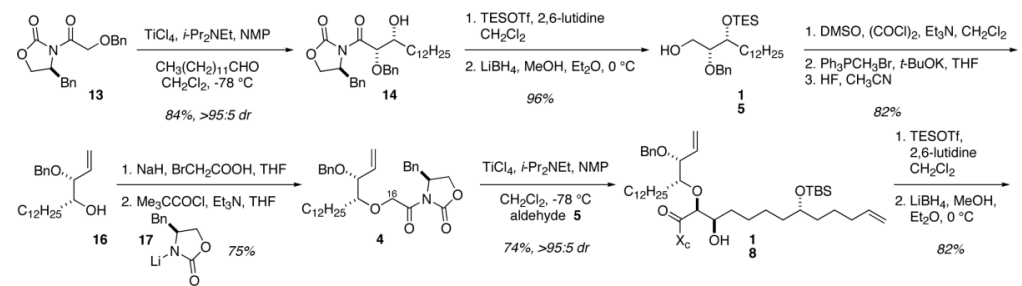

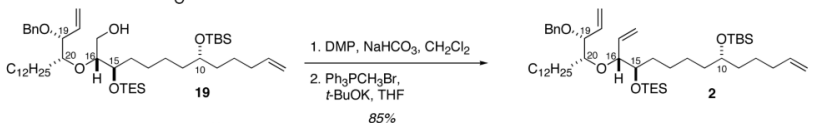

Scheme 1.

Preparation of triene $\mathbf{2}$ 


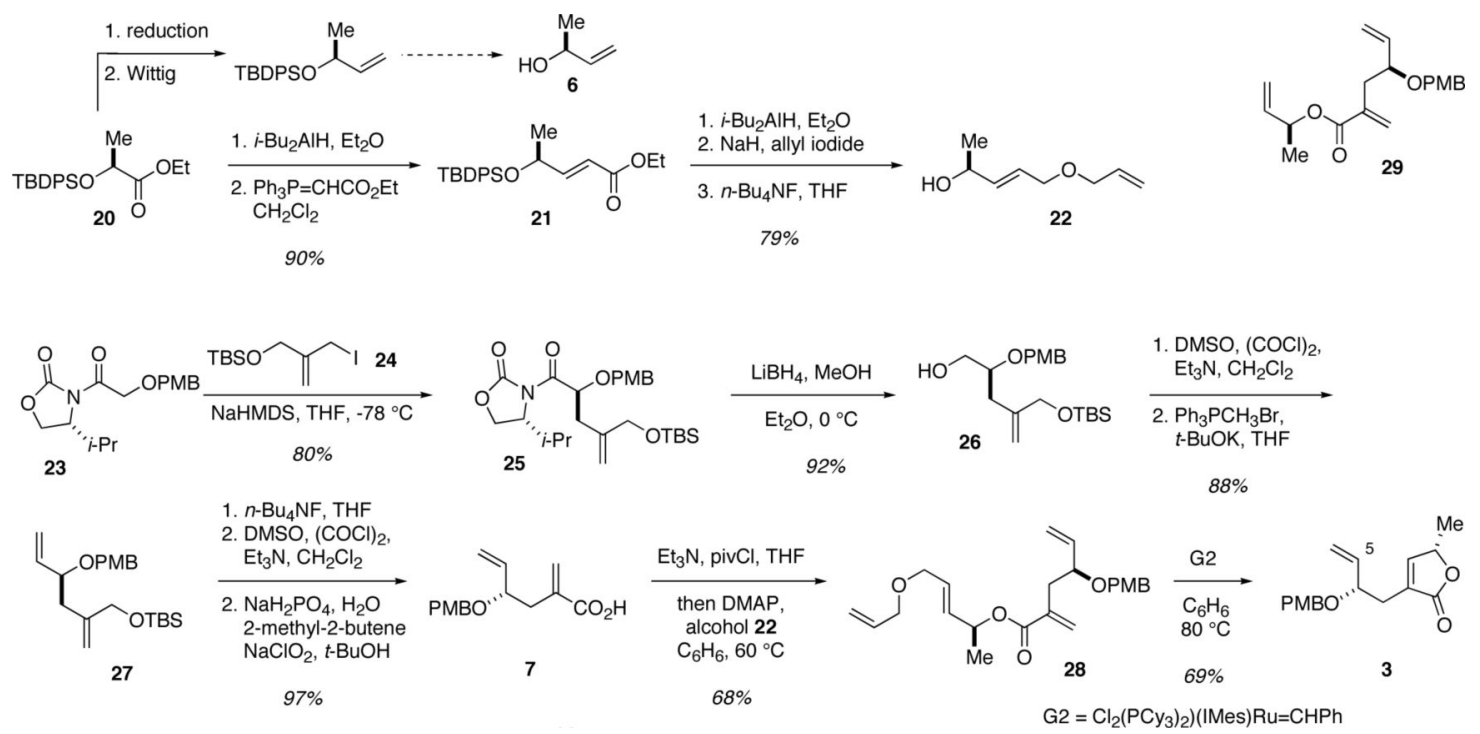

Scheme 2.

Preparation of butenolide $\mathbf{3}$ 


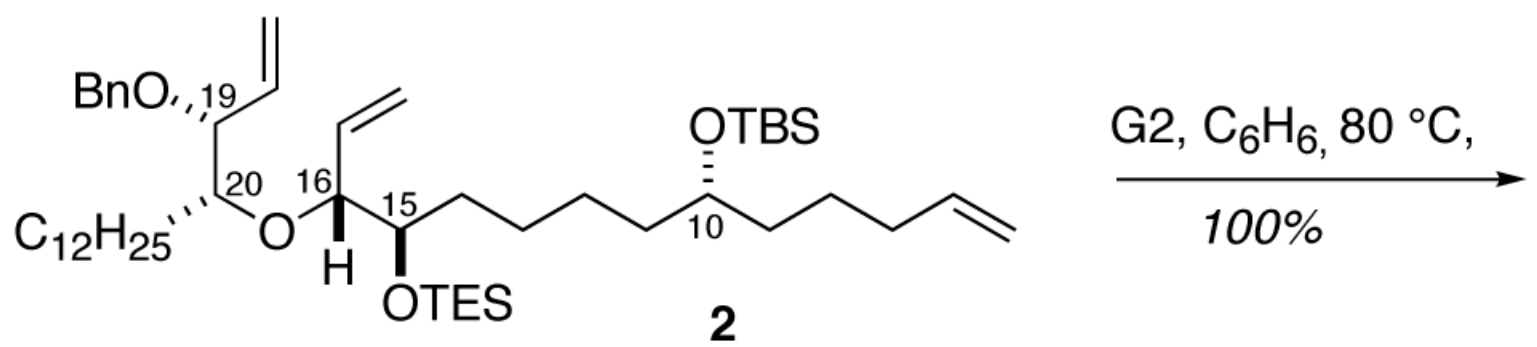

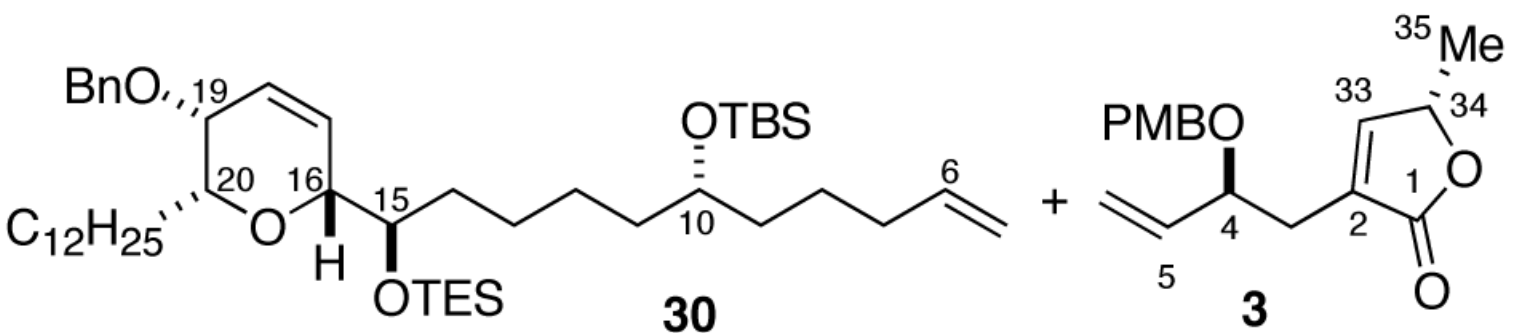

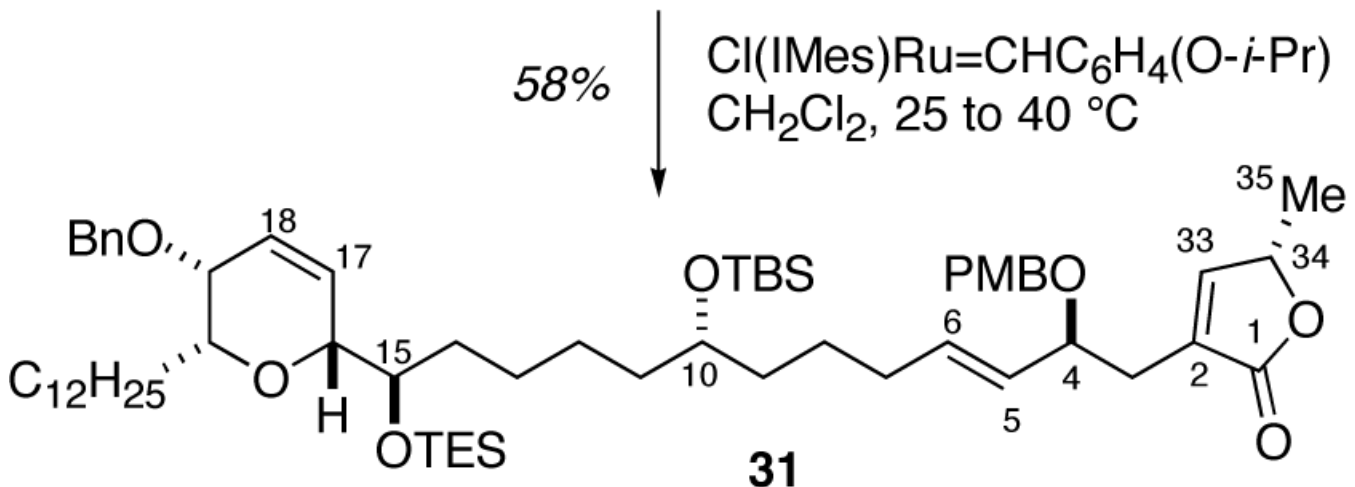

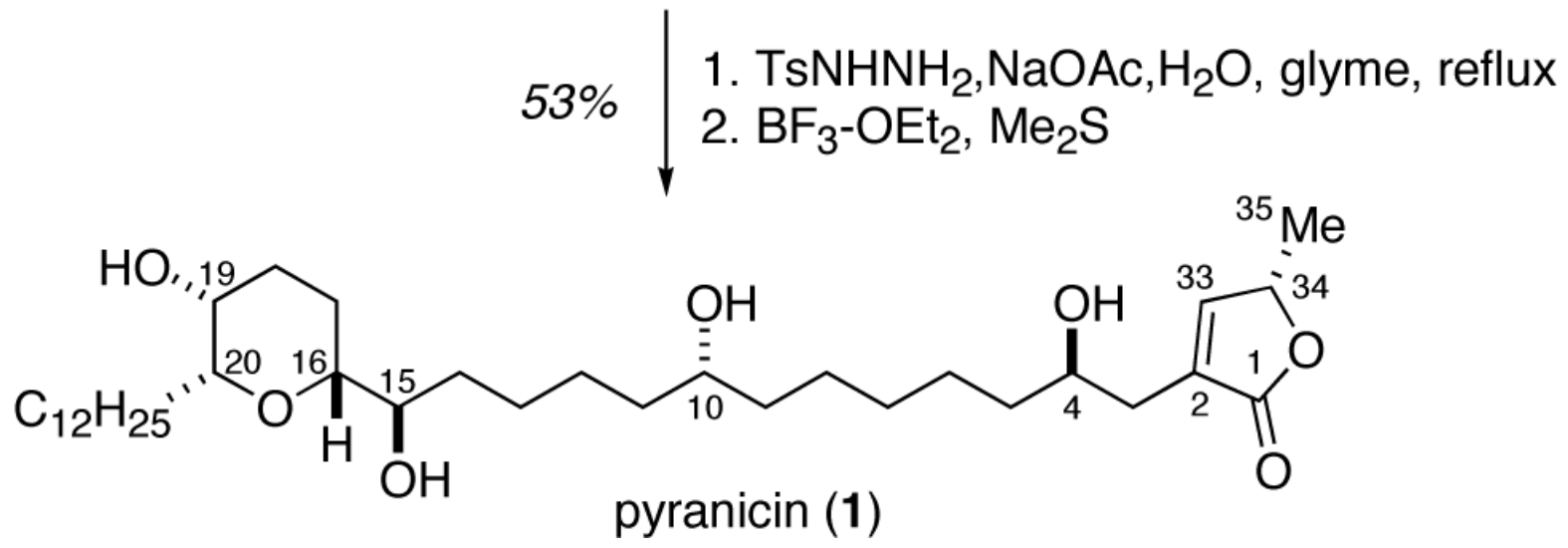

Scheme 3.

Completion of the synthesis 